\title{
Use of commercial mycorrhizal fungi in stress-free growing conditions of potted olive cuttings
}

\author{
M. Ângelo Rodrigues ${ }^{\mathrm{a}, *}$, Luísa Borsa Piroli ${ }^{\mathrm{b}}$, Douglas Forcelini ${ }^{\mathrm{b}, \mathrm{c}}$, Soraia Raimundo ${ }^{\mathrm{a}}$, \\ Lucas da Silva Domingues ${ }^{\mathrm{b}}$, Luís César Cassol ${ }^{\mathrm{b}, \mathrm{c}}$, Carlos Manuel Correia ${ }^{\mathrm{d}}$, Margarida Arrobas ${ }^{\mathrm{a}}$ \\ a Centro de Investigação de Montanha (CIMO), Instituto Politécnico de Bragança, Campus de Sta Apolónia, 5300-253, Bragança, Portugal \\ ${ }^{\mathrm{b}}$ Universidade Tecnológica Federal do Paraná/Campus Dois Vizinhos, Paraná, Brazil \\ ${ }^{c}$ Universidade Tecnológica Federal do Paraná/Campus Pato Branco, Paraná, Brazil \\ ${ }^{\mathrm{d}}$ Centre for the Research and Technology of Agro-Environmental and Biological Sciences (CITAB), University of Trás-os-Montes e Alto Douro, 5000-801, Vila Real, \\ Portugal
}

\section{A R T I C L E I N F O}

\section{Keywords:}

Biofertilizer

Ectomycorrhiza

Arbuscular mycorrhiza

Nutrient uptake

Soil organic carbon

Glomalin

\begin{abstract}
A B S T R A T
Biofertilizers of mycorrhizal fungi have been mainly tested in nutrient-limited soils or harsh environmental conditions, which have helped to highlight their beneficial role in plant growth. However, their benefits in stressfree growing conditions have not yet been properly proven. In this work, a commercial mycorrhizal fungi, composed of 18 ecto and endomycorrhizal fungi, was tested in a pot experiment with young olive cuttings, under an experimental apparatus allowing the evaluation of dry matter yield and plant nutritional status after one and two years of growth. The results highlighted the role of the mycorrhiza in increasing P bioavailability, either evaluated by soil P labile fraction or through tissue P concentration. The role of mycorrhiza in increasing soil organic $\mathrm{C}$ was also relevant (7\% higher than the control). Mycorrhiza had little effect on the uptake of other nutrients and on the alleviation of excessive levels of metals, in particular Fe, in the shoots. Instead, olive showed its own exclusion mechanisms, registering root Fe levels 50 times higher than in shoots. Mycorrhiza did not improve plant growth compared to the other fertilized treatments. The increase in plant dry matter observed in the mycorrhiza treatment in comparison to the control was probably due to the initial content of the commercial product of $\mathrm{N}, \mathrm{P}$ and $\mathrm{K}\left(3 \% \mathrm{~N}, 3 \% \mathrm{P}_{2} \mathrm{O}_{5}\right.$ and $\left.3 \% \mathrm{~K}_{2} \mathrm{O}\right)$. Under the conditions of this experiment, the farmer would not benefit from the use of this mycorrhizal fungi, but it nevertheless proved its value for agriculture, suggesting that commercial products should be targeted more towards specific purposes, than for generalized uses.
\end{abstract}

\section{Introduction}

Agricultural production systems are under increasing pressure. They have to ensure food for a growing world population, as well as raw materials for the textile, pharmaceutical and energy industries. On the other hand, high-input agricultural systems can cause tremendous environmental impacts, with soil degradation, water pollution and the emission of harmful gases into the atmosphere (Bunzel et al., 2014; Mendivil-Garcia et al., 2020). As society complains, researchers seek to develop more sustainable agricultural systems that ensure the production of goods, but with lesser environmental impacts.

Beneficial relationships between soil microorganisms and plants are scientifically well documented. Some beneficial microorganisms live in the rhizosphere, others invade intercellular spaces, and many enter the cells, forming mutualistic relationships with the host plants. These microorganisms provide diverse services to plants, such as access to nutrients, or protection against biotic or abiotic stresses. They receive, in exchange, privileged access to root exudates, or photoassimilates directly from the phloem (Valentine et al., 2013; Miransari, 2013; Lanfranco et al., 2016).

Some bacteria colonize the rhizosphere of several plant species, benefiting from exudates released by plants into the surrounding soil. In turn, they can increase plant nutrient uptake from soils and reduce their susceptibility to diseases. These bacteria are collectively known as plant growth-promoting rhizobacteria (PGPR) (Aeron et al., 2020). Some beneficial endophytic bacteria, known as plant growth-promoting bacteria (PGPB), have the ability to colonize and survive in the internal plant tissues without causing damage to the host, even though they can

\footnotetext{
* Corresponding author.

E-mail address: angelor@ipb.pt (M.Â. Rodrigues).
} 
live as free organisms in the soil or other environments (Ferrando and Fernández-Scavino, 2013). The beneficial effects to plants may be diverse, and PGPB can be categorized as biofertilizers, phytostimulators, stress controllers, and rhizoremediators (Fischer et al., 2013).

Soil fungi also establish important associations with higher plants. They colonize the roots of $90 \%$ of land plants, including agricultural and horticultural crop species (López-Ráez and Pozo, 2013; Lanfranco et al., 2016). The arbuscular mycorrhizal (AM) symbiosis, established between the roots of terrestrial plants and fungi of the subphylum Glomeromycotina, is one of the best-known beneficial plant-fungi associations to take place in the rhizosphere benefiting about $80 \%$ of plant species (Valentine et al., 2013). These associations date back to more than 400 million years ago when plants invaded the land, being considered a key step in the evolution of terrestrial plants (Remy et al., 1994). The AM symbiosis gives rise to the formation of extensive hyphal networks in the soil able to significantly increase the uptake of nutrients, notably phosphorus (P), and water (Miransari, 2013; Lanfranco et al., 2016). AM fungi may also increase the tolerance of plants against different types of abiotic and biotic stresses (Calvo-Polanco et al., 2013; Zhan et al., 2018). In turn, AM fungi are obligate biotrophs, dependent on a source of carbon (C) from the host plant (Valentine et al., 2013). Other fungal endophytes may colonize plant roots without establishing mycorrhizal associations such as the formation of arbuscules. Fungal endophytes are micromycetes which grow internally in living plant tissues showing a continuum of interactions with their host ranging from positive, neutral or even negative responses (Andrade-Linares and Franken, 2013). Ectomycorrhizal fungi may also have beneficial interactions with plants. Many tree species form symbiotic associations with ectomycorrhizal fungi which are known to enhance the uptake of nutrients by plants (Kieliszewska-Rokicka, 1999; Ågren et al., 2019) or which provide protection by alleviating them of heavy metal toxicity (Luo et al., 2014; Egerton-Warburton, 2015).

Although there is no doubt about the importance of microorganisms for plants, the agronomic effectiveness of the use of commercial biofertilizers is still uncertain, with the probable exception of rhizobia in the inoculation of legumes species. As with the symbiotic rhizobicleguminous associations, the benefits for the host plant may depend on plant (species, cultivars) and microbe (ecotypes, strains) combinations and environmental conditions (López-Ráez and Pozo, 2013; Chatzistathis et al., 2013). Most of the studies using beneficial microorganisms take place under very artificial conditions, which facilitate the observation of the beneficial effects on plants, such as the use of sterilized soil, nutrient-limited soils or other unfavourable environmental conditions for plant growth (Wu and Zou, 2010; Bati et al., 2015; Ouledali et al., 2018). It is necessary, however, to take into account that most plants naturally establish symbiotic relationships with microorganisms. It is also reasonable to assume that indigenous microorganisms are ecologically well adapted, providing the services that local plants need. The relevant question, therefore, is whether agriculture in general can benefit from the use of biofertilizers or whether they should be developed for very specific species, cultivars or ecological niches. At present, when a biofertilizer is developed for the market, there is a tendency to apply it on a widespread scale, mainly for commercial reasons. Furthermore, to increase the probability of obtaining a benefit for the host plant over a wide range of conditions, some manufactures include many different microorganisms in the same product (Vessey, 2003; Rodrigues et al., 2018).

In this work, a commercial mycorrhizal fungi was evaluated in a normal agricultural situation, from rooting to the transplantation phase of olive cuttings, following procedures similar to those carried out in a commercial nursery. A commercial mycorrhizal fungi was used, containing 18 species of ecto- and endomycorrhizal fungi. We tested the hypothesis as to whether the commercial product can improve the growth of plants and their nutritional status and, indirectly, farmers' profits. The experimental apparatus, with differentiated applications of $\mathrm{N}, \mathrm{P}$ and potassium $(\mathrm{K})$, was able to provide information as to which nutrients are mostly readily absorbed, or not, by the mycorrhiza.

\section{Materials and methods}

\subsection{Establishment of the pot experiment}

The pot experiment was carried out in Bragança, NE Portugal, in indoor conditions. The cover of the greenhouse consists of a double-wall polycarbonate panel. Aeration and heat dissipation in summer relies on lateral and zenithally openings and reflective screen.

The experiment consisted of a completely randomized design with the following six treatments: Mycorrhiza (commercial mycorrhizal fungi, applied at a rate of $15 \mathrm{~g} \mathrm{pot}^{-1}$, containing $0.45 \mathrm{~g} \mathrm{~N}, \mathrm{P}_{2} \mathrm{O}_{5}$ and $\mathrm{K}_{2} \mathrm{O}$ ); NPK $\left(0.45 \mathrm{~g} \mathrm{pot}^{-1}\right.$ of N, $\mathrm{P}_{2} \mathrm{O}_{5}$ and $\mathrm{K}_{2} \mathrm{O}$ ); NPK $+\mathrm{N}$ (similar to NPK plus an extra dose of $0.45 \mathrm{~g} \mathrm{~N}$ pot $^{-1}$ ); NPK $+\mathrm{P}$ (similar to NPK plus an extra dose of $0.45 \mathrm{~g} \mathrm{P}_{2} \mathrm{O}_{5}$ pot $^{-1}$ ); NPK $+\mathrm{K}$ (similar to NPK plus an extra dose of $0.45 \mathrm{~g} \mathrm{~K}_{2} \mathrm{O}$ pot $^{-1}$ ); and Control (non-fertilized).

The commercial product is derived from poultry compost, feathermeal, diammonium phosphate, potassium sulphate, ammonium sulphate, kelp meal, dolomite lime, ferrous sulphate. Nutrient concentration is $3 \% \mathrm{~N}, 3 \% \mathrm{P}_{2} \mathrm{O}_{5}, 3 \% \mathrm{~K}_{2} \mathrm{O}, 4 \%$ calcium (Ca), $1.5 \%$ magnesium $(\mathrm{Mg}), 1 \%$ sulphur $(\mathrm{S})$ and $1 \%$ water soluble iron $(\mathrm{Fe})$. It contains also $0.40 \%$ humic acids, $0.15 \%$ ascorbic acid, $0.05 \%$ glycine, $0.02 \%$ Myo-inositol, and $0.01 \%$ thiamine mononitrate. The biofertilizer contains a total of 18 species of microorganisms, nine ecto- and nine endomycorrhizal (arbuscular) fungi. The ectomycorrhizal fungi are Pisolithus tinctorius, Rhizopogon spp. (four species), Scleroderma spp. (two species) and Laccaria spp. (two species). Regarding the arbuscular micorrhizal fungi, seven are of the genus Glomus and the other two species are Rhizophagus irregularis and Paraglomus brasilianum.

Table 1

Selected properties (average \pm standard deviation) of the soil used in the pot experiment.

\begin{tabular}{|c|c|c|c|}
\hline \multicolumn{2}{|l|}{ Soil properties } & \multicolumn{2}{|l|}{ Soil properties } \\
\hline${ }^{\mathrm{a}}$ Clay (\%) & 23.9 & ${ }^{\mathrm{e}}$ Extractable $\mathrm{P}\left(\mathrm{mg} \mathrm{P} \mathrm{P}_{2} \mathrm{O}_{5} \mathrm{~kg}^{-1}\right)$ & $33.1 \pm 2.82$ \\
\hline${ }^{\mathrm{a}}$ Silt (\%) & 21.8 & ${ }^{\mathrm{e}}$ Extractable $\mathrm{K}\left(\mathrm{mg} \mathrm{K}_{2} \mathrm{O} \mathrm{kg}^{-1}\right)$ & $55.4 \pm 6.13$ \\
\hline${ }^{\mathrm{a}}$ Sand $(\%)$ & 54.4 & ${ }^{\mathrm{f}}$ Exchang. Ca $\left(\mathrm{cmol}_{\mathrm{c}} \mathrm{kg}^{-1}\right)$ & $21.7 \pm 0.31$ \\
\hline${ }^{\mathrm{b}} \mathrm{pH}\left(\mathrm{H}_{2} \mathrm{O}\right)$ & $6.2 \pm 0.06$ & ${ }^{\mathrm{f}}$ Exchang. $\mathrm{Mg}\left(\mathrm{cmol}_{\mathrm{c}} \mathrm{kg}^{-1}\right)$ & $5.3 \pm 0.15$ \\
\hline${ }_{\mathrm{pH}}^{\mathrm{b}}(\mathrm{KCl})$ & $5.4 \pm 0.12$ & ${ }^{\mathrm{f}}$ Exchang. K $\left(\mathrm{cmol}_{\mathrm{c}} \mathrm{kg}^{-1}\right)$ & $0.3 \pm 0.06$ \\
\hline${ }^{c}$ Organic carbon $\left(\mathrm{g} \mathrm{kg}^{-1}\right)$ & $8.5 \pm 0.21$ & ${ }^{\mathrm{f}}$ Exchang. $\mathrm{Na}\left(\mathrm{cmol}_{\mathrm{c}} \mathrm{kg}^{-1}\right)$ & $0.6 \pm 0.10$ \\
\hline${ }^{\mathrm{d}}$ Extractable B $\left(\mathrm{mg} \mathrm{kg}^{-1}\right)$ & $0.8 \pm 0.06$ & ${ }^{\mathrm{g}}$ Exchang. acidity $\left(\mathrm{cmol}_{\mathrm{c}} \mathrm{kg}^{-1}\right)$ & $0.1 \pm 0.00$ \\
\hline
\end{tabular}

\footnotetext{
${ }^{a}$ Robinson pipette method.

b Potentiometry.

c Walkley-Black.

d Hot water, azomethine-H.

e Ammonium lactate.

f Ammonium acetate.

$g$ Potassium chloride.
} 

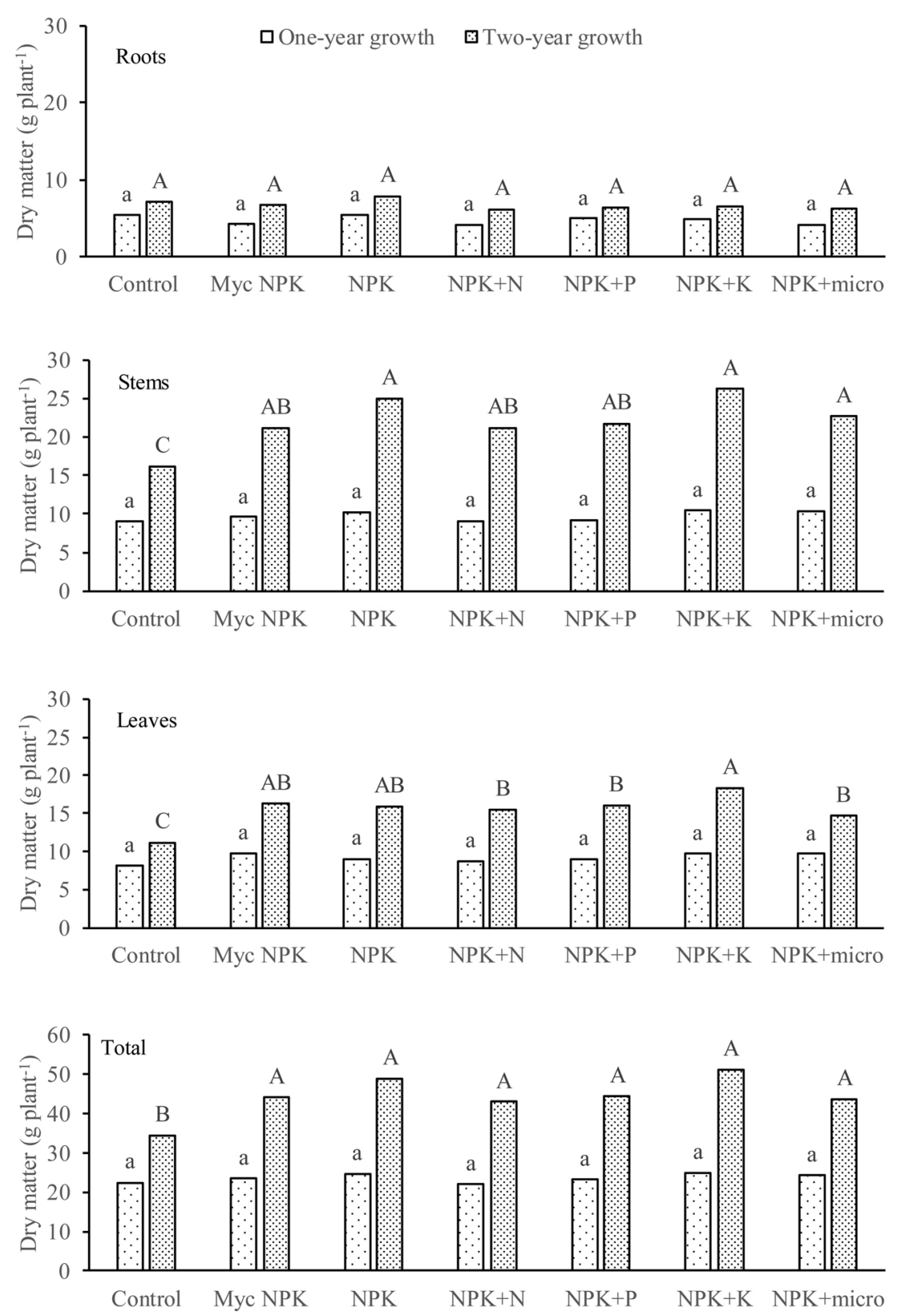

Fig. 1. Roots, stems, leaves and total dry matter yield from one-year and two-year growth plants as a function of the fertilizer treatments. Letters above the columns is the result of ANOVA and Tukey HSD test $(\alpha=0.05)$ separately from one-year (lowercase) and two-year (uppercase) growth plants.

Table 2

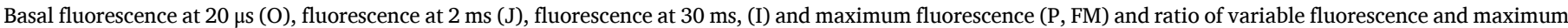

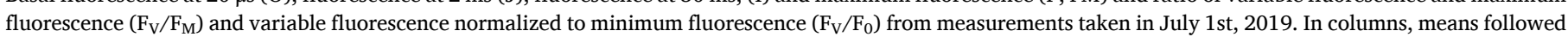
by the same letter are not significantly different by Tukey HSD test $(\alpha=0.05)$.

\begin{tabular}{|c|c|c|c|c|c|c|c|c|c|c|c|c|}
\hline Treatment & $\mathrm{O}$ & & $\mathrm{J}$ & & I & & $P$ & & $\mathrm{~F}_{\mathrm{V}} / \mathrm{F}_{\mathrm{M}}$ & & $\mathrm{F}_{\mathrm{V}} / \mathrm{F}_{0}$ & \\
\hline Control & 290.0 & $\mathrm{a}$ & 467.5 & a & 973.0 & a & 1139.0 & a & 0.808 & $\mathrm{~b}$ & 4.254 & a \\
\hline Mycorrhiza & 251.0 & a & 404.0 & a & 861.0 & a & 1069.5 & $\mathrm{a}$ & 0.827 & a & 4.801 & a \\
\hline NPK & 256.5 & a & 410.0 & a & 875.5 & a & 1097.0 & a & 0.828 & a & 4.816 & $\mathrm{a}$ \\
\hline $\mathrm{NPK}+\mathrm{N}$ & 267.0 & $\mathrm{a}$ & 430.5 & $\mathrm{a}$ & 947.5 & a & 1149.0 & a & 0.822 & $\mathrm{a}$ & 4.617 & a \\
\hline $\mathrm{NPK}+\mathrm{P}$ & 234.0 & $\mathrm{a}$ & 368.0 & a & 828.0 & a & 1062.0 & a & 0.826 & a & 4.741 & $\mathrm{a}$ \\
\hline $\mathrm{NPK}+\mathrm{K}$ & 247.5 & $\mathrm{a}$ & 392.0 & a & 850.0 & a & 1075.5 & a & 0.828 & a & 4.815 & $\mathrm{a}$ \\
\hline
\end{tabular}

Commercial advertising recommends this type of formulation for disturbed or poor soils and new plantings of all valuable trees and shrubs. N, P and K in the NPK fertilized treatments were applied respectively as ammonium nitrate $(34.5 \% \mathrm{~N})$, simple superphosphate $\left(18 \% \mathrm{P}_{2} \mathrm{O}_{5}\right)$ and potassium chloride $\left(60 \% \mathrm{~K}_{2} \mathrm{O}\right)$.
The pots were filled with $3 \mathrm{~kg}$ of dry and sieved ( $2 \mathrm{~mm}$ mesh) soil mixed with the fertilizer reported in the experimental design. The main properties of the soil used in this experiment are presented in Table 1. Semi hardwood rooted 'Cobrançosa' cuttings, $\sim 20 \mathrm{~cm}$ high, were planted in October, 12th 2017. From the beginning there were prepared 

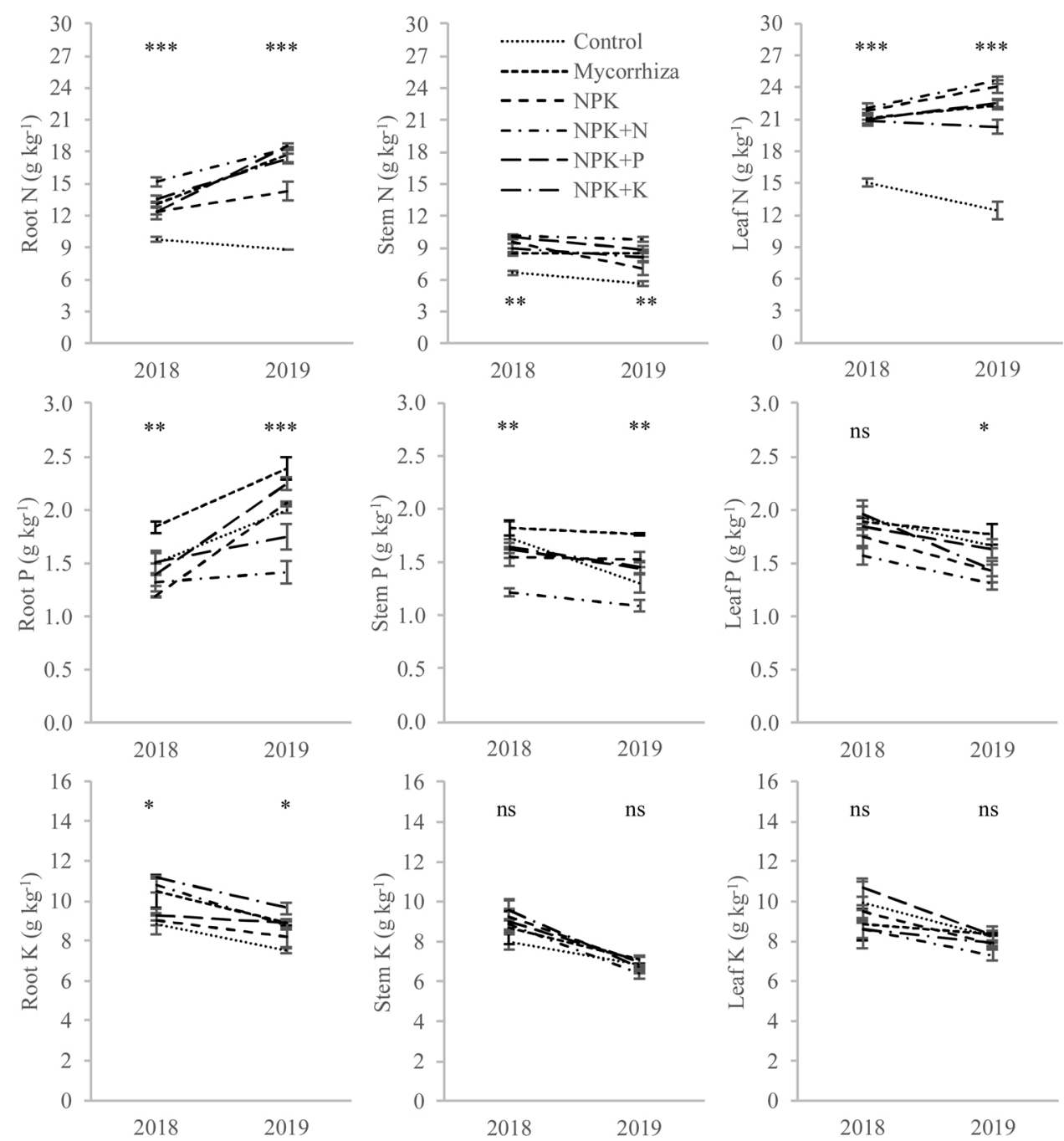

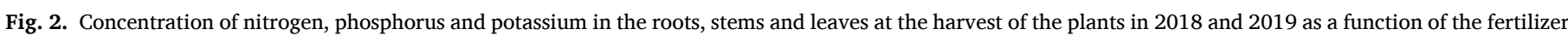
treatment. ns, not significant; * $P<0.05$; ** $P<0.01$; *** $P<0.001$ ). Error bars are the mean standard deviations.

seven replications (pots) per each treatment. After the experiment was installed the weeds were uprooted in a timely manner to reduce nutrient uptake. The plants were also watered manually during the experimental period. Appropriations of $150 \mathrm{~mL}$ were used for each irrigation. The number of weekly waterings varied greatly throughout the year, depending on the environmental conditions prevailing inside the greenhouse. The irrigation frequency was adjusted in order to avoid exceeding the field capacity and to create anaerobic conditions. Plates were placed under the pots to prevent nutrient loss from leaching. In October 9th 2018, three random pots of the seven replications were used for plant analysis evaluation. The young plants were separated into roots, stems and leaves. Tissue samples were oven-dried at $70{ }^{\circ} \mathrm{C}$, weighed and ground for elemental analysis.

In the remaining four replications, the soil of the pots (about two thirds) was partially removed for a bucket and mixed with a second rate of the six fertilized treatments. The mixture of soil and fertilizers was put back into the pots and the irrigation maintained for more one year. In October 4th 2019, the more atypical plant of each treatment was eliminated being kept three replications per treatment. Firstly, a soil sample was recovered from each pot, consisting on almost all the soil of the pot. These soil samples were oven-dried at $40{ }^{\circ} \mathrm{C}$ before analysis. The plants were separated into roots, stems and leaves, following the methodology referred to the first harvest.

\subsection{Determinations during the growing seasons}

Chlorophyll $a$ fluorescence and O-J-I-P transient was determined by using the dark adaptation protocols $\mathrm{F}_{\mathrm{V}} / \mathrm{F}_{\mathrm{M}}, \mathrm{F}_{\mathrm{V}} / \mathrm{F}_{0}$ and the advanced OJIP test by using the OS-30p + chlorophyll meter. $\mathrm{F}_{\mathrm{M}}, \mathrm{F}_{0}$ and $\mathrm{F}_{\mathrm{V}}$ are, respectively, the maximum, minimum and variable fluorescence from dark adapted leaves, and $\mathrm{F}_{\mathrm{V}} / \mathrm{F}_{\mathrm{M}}=\left(\mathrm{F}_{\mathrm{M}^{-}}-\mathrm{F}_{0}\right) / \mathrm{F}_{\mathrm{M}}$ and $\mathrm{F}_{\mathrm{V}} / \mathrm{F}_{0}=\left(\mathrm{F}_{\mathrm{M}^{-}}-\mathrm{F}_{0}\right) / \mathrm{F}_{0}$. The OJIP test provides origin fluorescence at $20 \mu \mathrm{s}(\mathrm{O})$, fluorescence at 2 $\mathrm{ms}(\mathrm{J})$, fluorescence at $30 \mathrm{~ms}(\mathrm{I})$ and maximum fluorescence ( $\mathrm{P}$, or $\mathrm{F}_{\mathrm{M}}$ ). The fluorometer uses a pulse modulated detection system to allow for a variety of tests, with high capability for detecting and measuring plant stress types that affect photosystem II. Measurements were taken from fully expanded young leaves, after a period of dark adaptation longer than $35 \mathrm{~min}$. The dates of measurements were July 6 th and September 27th 2018 and July 1st and August 21st 2019.

\subsection{Soil and plant analysis}

Soil samples were oven-dried at $40{ }^{\circ} \mathrm{C}$ and submitted to analytical determinations: 1) $\mathrm{pH}\left(\mathrm{H}_{2} \mathrm{O}\right.$ and $\left.\mathrm{KCl}\right)$ (by potentiometry); 2) organic $\mathrm{C}$ (Walkley- Black method); 3) cation exchange capacity (ammonium acetate, $\mathrm{pH}$ 7.0); 4) extractable $\mathrm{P}$ and $\mathrm{K}$ (ammonium lactate solution at $\mathrm{pH}$ 3.7); 5) labile $\mathrm{P}$ fraction, $\mathrm{Pbic}$ (Pi extracted by $\mathrm{NaHCO}_{3} 0.5 \mathrm{M}$ ) and Pres 

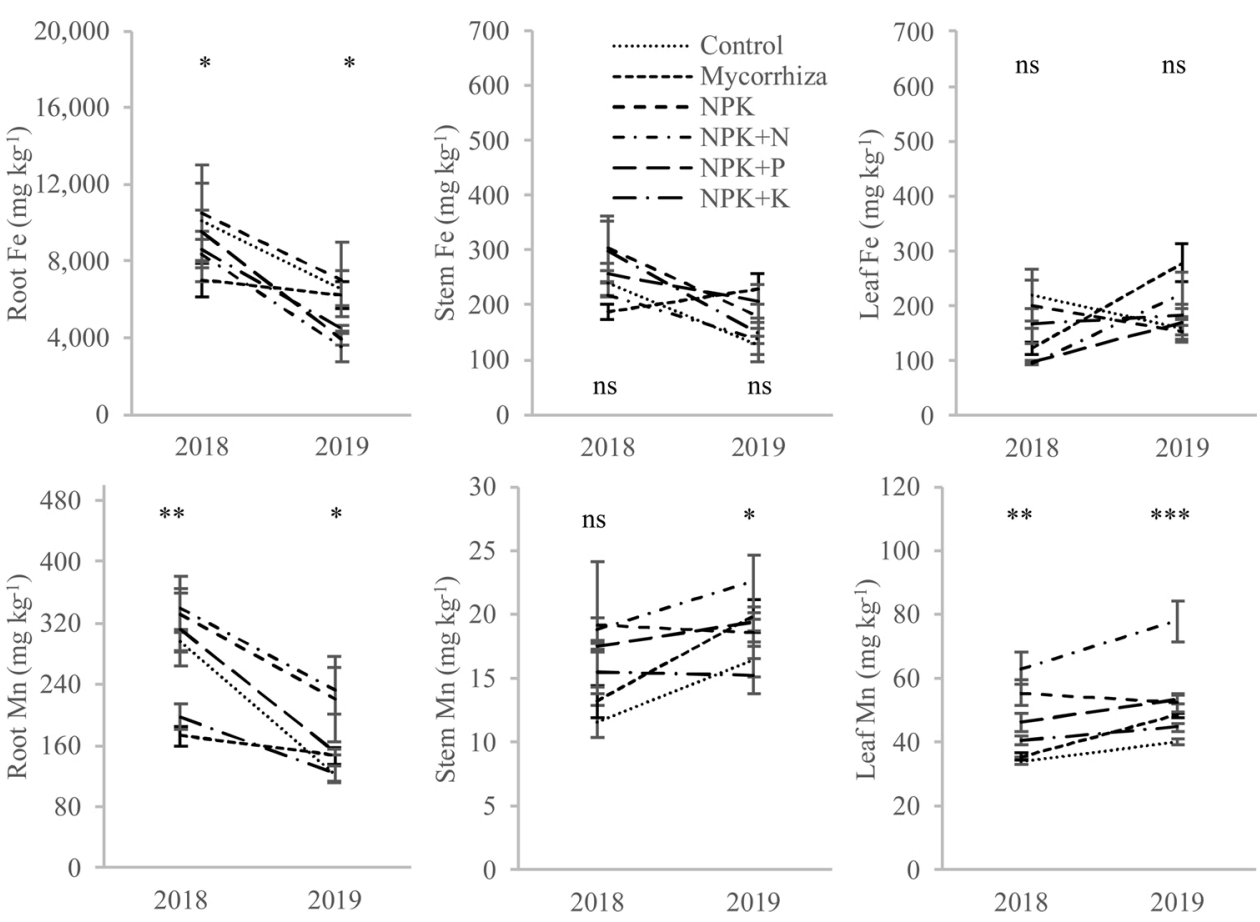

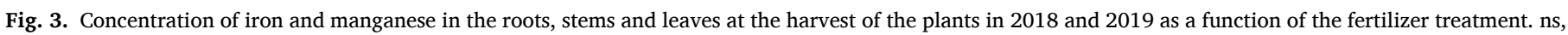
not significant; *, $P<0.05 ; * *, P<0.01 ; * * *, P<0.001)$. Error bars are the mean standard deviations.

(extraction of $\mathrm{Pi}$ with the $\mathrm{HCO}_{3}^{-}$ion present in an anion exchange resin, and then eluted in acid media); 6) extractable boron (B) (hot water, and azomethine-H method); 7) extractable $\mathrm{Fe}$, manganese (Mn), zinc ( $\mathrm{Zn}$ ) and cooper $(\mathrm{Cu})$ (ammonium acetate and EDTA, determined by atomic absorption spectrometry); 8) acid phosphatase activity (determined from the conversion of nitrophenylphosphate to nitrophenolphosphate); and 9) easily extractable glomalin-related soil protein (GRSP) and total GRSP concentrations were extracted, respectively, with $20 \mathrm{mM}$ citrate (pH 7.0) and $50 \mathrm{mM}$ citrate ( $\mathrm{pH}$ 8.0). In the initial samples there were also determined 10) clay, silt and sand fractions (Robinson pipette method). Methods $1-3$ and 5, 7 and 10 are fully described by van Reeuwijk (2002), method 4 by Balbino (1968), method 6 by Jones (2001), method 8 by Alef et al. (1995), and method 9 by Wright and Updahyaya (1998).

Plant tissues were oven-dried at $70{ }^{\circ} \mathrm{C}$ and ground. Elemental analyses of all the tissues (leaves, stems and roots) were performed by Kjeldahl (N), colorimetry (B and P), and atomic absorption spectrophotometry ( $\mathrm{K}, \mathrm{Ca}, \mathrm{Mg}, \mathrm{Fe}, \mathrm{Mn}, \mathrm{Cu}, \mathrm{Zn}$ ) methods (Temminghoff and Houba, 2004) after tissue samples were digested with nitric acid in a microwave.

\subsection{Data analysis}

Data analysis was carried out using JMP ${ }^{\circledR}$ software. Data was firstly tested for normality and homogeneity of variances using the ShapiroWilk test and Bartlett's test, respectively. The comparison of the effect of the fertilizer treatments was provided by one-way ANOVA. When significant differences were found $(\alpha<0.05)$, the means were separated by the multiple range Tukey HSD test $(\alpha=0.05)$.

\section{Results}

\subsection{Dry matter yield and plant performance}

After the first season of growth no significant differences were found among the fertilizer treatments in dry matter yield of roots, stems, leaves or total (Fig. 1). In the second growing season only the dry matter yield of roots did not vary with the fertilizer treatments. In general terms, the control treatment gave lower dry matter yields of stems, leaves and total in comparison to the fertilized treatments. The proportion of roots, stems and leaves in the total dry matter yield was $20.5,47.0$ and $32.5 \%$ in the control (the treatment producing lower total dry matter yield in the second growing season) and 12.9, 51.3 and $35.8 \%$ in NPK $+\mathrm{K}$ (the treatment producing the higher average total dry matter yield).

Chlorophyll $a$ fluorescence OJIP transient did not reveal significant differences in the nutritional stress among the plants of the different fertilized treatments in four measurement performed in 2018 (July 6th and September 27th) and 2019 (July 1st and August 21st). Thus, only the data of the measurements taken in July 1st, 2019, were presented in Table 2. In this date, the ratio of variable fluorescence and maximum fluorescence $\left(\mathrm{F}_{\mathrm{V}} / \mathrm{F}_{\mathrm{M}}\right)$ was significantly lower in the control in comparison to the fertilized treatments.

\subsection{Plant tissue nutrient concentration and nutrient removal}

The concentration of $\mathrm{N}$ in the roots, stems and leaves significantly varied among the fertilizer treatments in both sampling dates (Fig. 2). The control treatment showed tissue $\mathrm{N}$ concentrations markedly lower when compared to the other treatments. The treatment NPK $+\mathrm{N}$ showed a tendency to display the average higher values even when compared with the other fertilized treatments. The concentration of $\mathrm{P}$ in plant tissues significantly varied among the fertilizer treatments in almost all the tissues and sampling dates. The single exception was the leaf P levels in the harvest of 2018, in which no significant differences among fertilizer treatments was found. In the case of $\mathrm{P}$ concentration in plant tissue the aspect that should be highlighted is the high $\mathrm{P}$ values associated to the Mycorrhiza treatment. The NPK $+\mathrm{N}$ treatment usually gave the lower levels of $\mathrm{P}$ in plant tissues. The fertilizer treatments had a smaller effect on tissue $\mathrm{K}$ levels in comparison to $\mathrm{N}$ and $\mathrm{P}$. Only in the roots, significant differences among the fertilizer treatments were observed, and the higher values were associated to the NPK $+\mathrm{K}$ treatment. The control treatments gave the lower $\mathrm{K}$ values. The effect of the fertilizer treatments on the other macronutrients analysed (Ca and $\mathrm{Mg}$ ) was not statistically significant for any of the harvest date (data not 

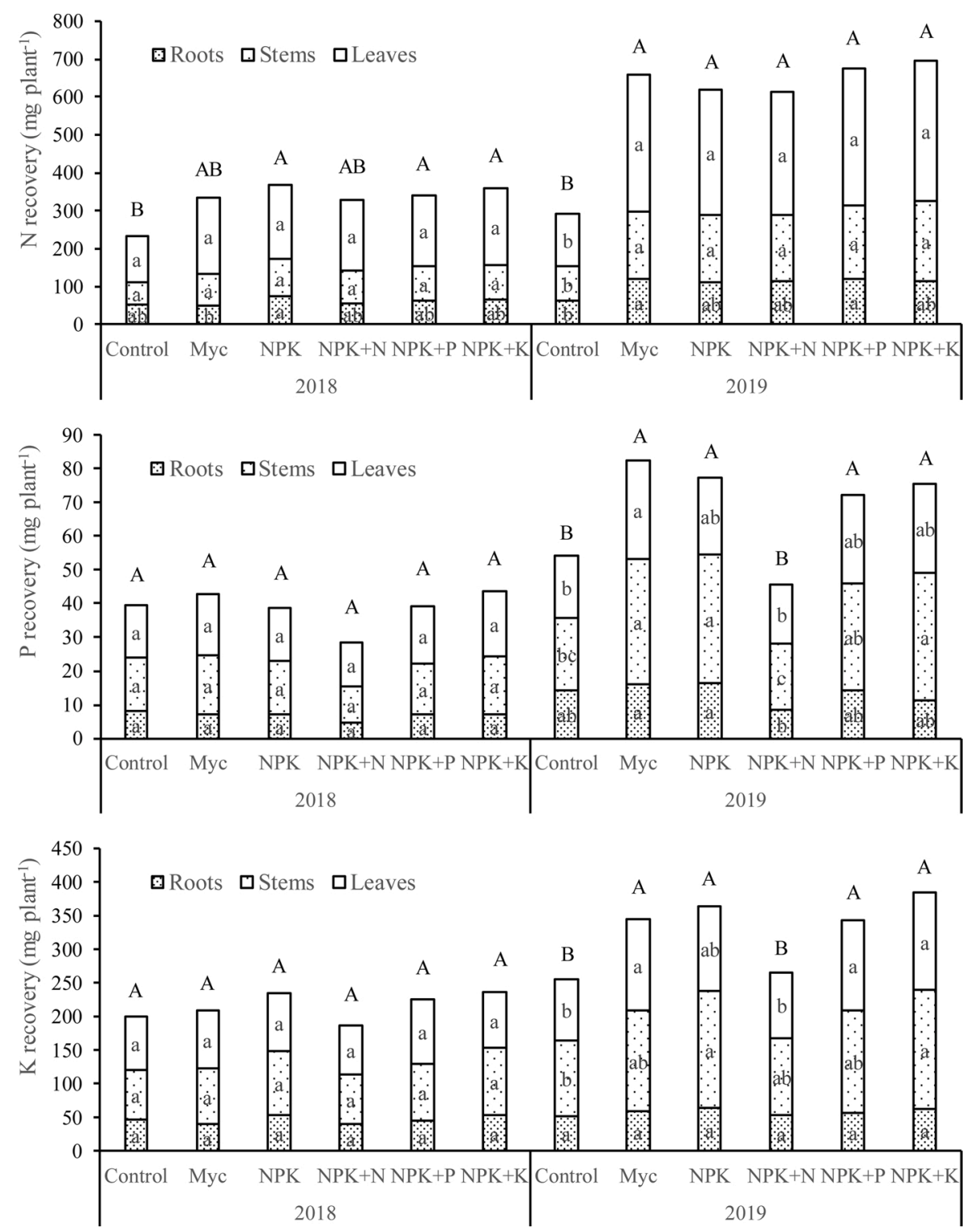

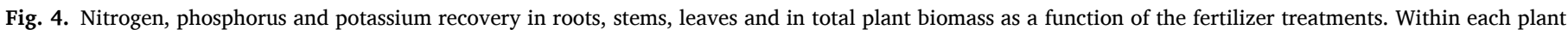

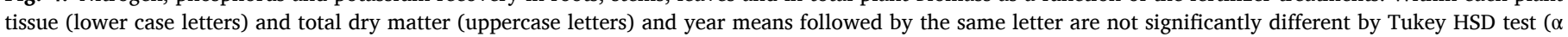
$=0.05$ ).

shown).

The levels of $\mathrm{Fe}$ in the roots, stems and leaves did not reveal any noticeable effect caused by the different fertilizers treatments (Fig. 3). It was observed a great experimental variability which reduced the occurrence of significant differences between treatments for the majority of plant tissues. However, it should be noted the higher levels of Fe in the roots compared to the values observed in the shoots. The average concentration of $\mathrm{Fe}$ in the roots, in the first sampling, ranged from 7023 to $10,504 \mathrm{mg} \mathrm{kg}^{-1}$, while in the leaves they ranged from 95 to $221 \mathrm{~g}$ $\mathrm{kg}^{-1}$, with a general tendency to be about 50 times higher. The levels of $\mathrm{Mn}$ in the tissues tended to be higher in the treatment NPK $+\mathrm{N}$ in all tissues and in general in the two sampling dates. The high experimental variability was also relevant even though significant differences have occurred on both sampling dates and tissues. The levels of Mn also proved to be much higher in the roots compared to the leaves, especially in the first sampling. In the roots they ranged from 172 to $339 \mathrm{mg} \mathrm{kg}^{-1}$ and in the leaves from 34 to $63 \mathrm{mg} \mathrm{kg}^{-1}$. In the concentration of $\mathrm{Zn}$ in the tissues, there were practically not found significant differences between treatments, nor a clear trend that could be related to the fertilizer treatments (data not shown). The samples were marked by high experimental variability, as already mentioned for the previous metal micronutrients. Zn concentrations in the roots, however, were also much higher than in the shoots. In the roots they varied between $40-100 \mathrm{mg}$ $\mathrm{kg}^{-1}$ and in the leaves between $20-50 \mathrm{mg} \mathrm{kg}{ }^{-1}$. The pattern described for $\mathrm{Zn}$ was also observed for $\mathrm{Cu}$, without a clear trend between treatments (data not shown). The values in the roots were also higher than in the leaves, varying between $60-80 \mathrm{mg} \mathrm{kg}^{-1}$ and $8-16 \mathrm{mg} \mathrm{kg}^{-1}$ respectively. Tissue B levels also did not show any consistent trend according to the fertilizer treatments, and significant differences were rare (data not shown). However, contrarily to the other micronutrients, the concentration of B in the roots was lower than in the shoots. B average levels varied from 10 to $19 \mathrm{mg} \mathrm{kg}^{-1}$ in the roots, $15-22 \mathrm{mg} \mathrm{kg}^{-1}$ in the stems and $18-27 \mathrm{mg} \mathrm{kg}^{-1}$ in the leaves.

Nutrient removal provides the combined effect of the fertilizer treatments on dry matter yield and nutrient concentration in plant tissues (Fig. 4). It is an attempt to stress the effect of the treatments, due to the multiplicative effect of the production of dry matter and its concentration in nutrients. In the sampling of 2018, the effect of the 

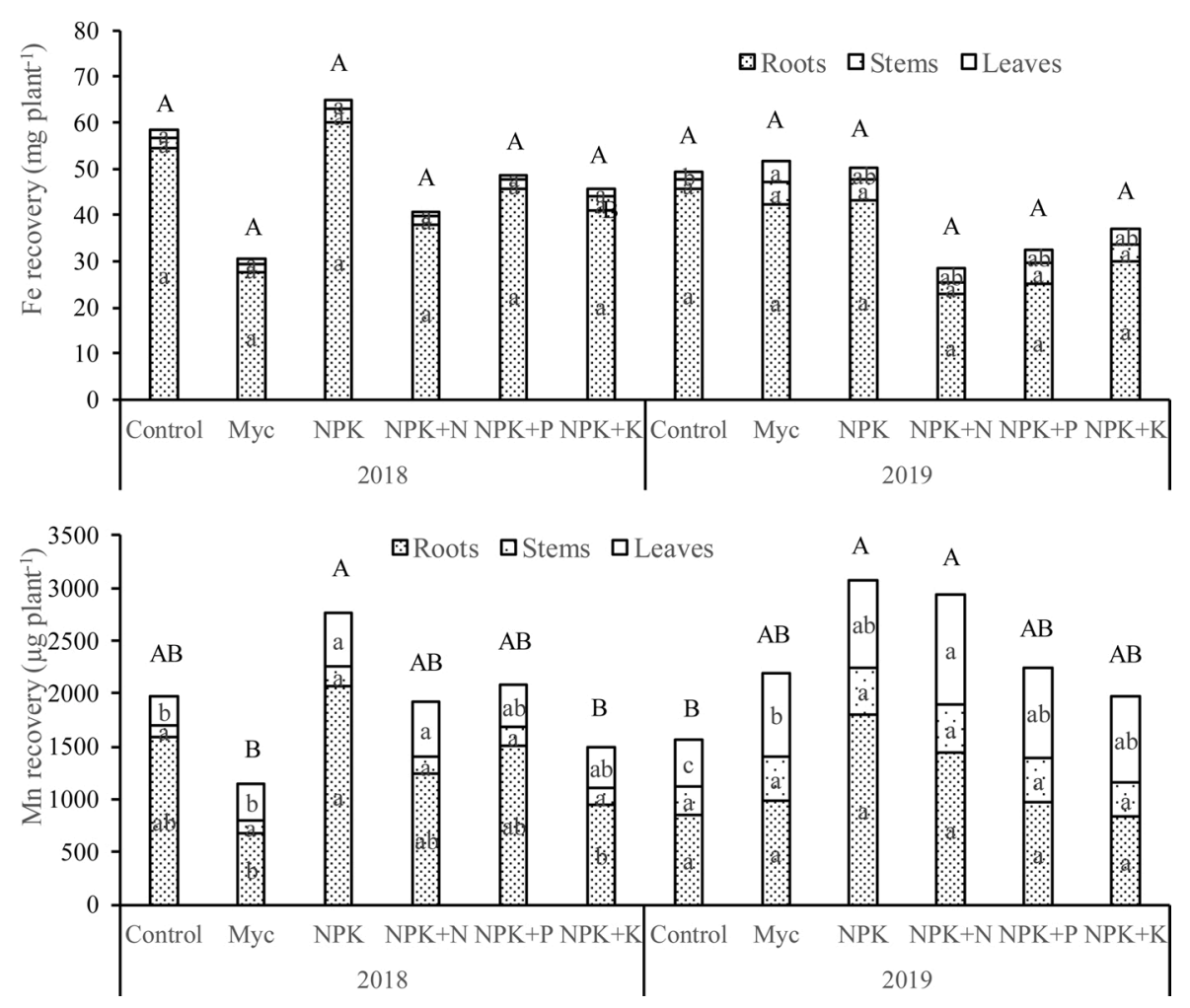

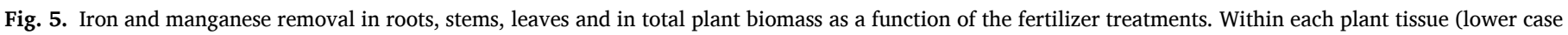
letters) and total dry matter (uppercase letters) and year means followed by the same letter are not significantly different by Tukey HSD test ( $\alpha=0.05$ ).

treatments on $\mathrm{N}$ recovery was significant to the root and total biomass. In the sampling of 2019, however, the control showed significantly lower values of $\mathrm{N}$ recovery in each individual tissue and in total dry mass in comparison to the fertilized treatments. No significant differences were found among the fertilized treatments in $\mathrm{N}$ recovery in total dry mass in the individual plant parts. In the first sampling in 2018, there were not observed significant differences in the amount of $\mathrm{P}$ recovered in each of the tissues and in the entire plant. The NPK $+\mathrm{N}$ treatment showed, however, the lowest average values of P recovered. In the 2019 sampling there were found significant differences in the $P$ recovered in each of the tissues and in the entire plant. The lowest values were recorded in the NPK $+\mathrm{N}$ treatment, followed by the Control. The Mycorrhiza treatment showed the highest average value of $\mathrm{P}$ recovered in the entire plant. In 2018, the first year of sampling, there were not observed significant differences between treatments in $\mathrm{K}$ recovery. In 2019 there were found significant differences between treatments in $\mathrm{K}$ recovered in the stems, leaves and total dry mass. The lowest $\mathrm{K}$ values in the total dry mass were recorded in the Control followed by the NPK $+\mathrm{N}$ treatment. The highest average value of $\mathrm{K}$ in the entire plant was recorded in the NPK $+\mathrm{K}$ treatment.

The values of Fe recovery did not vary significantly with fertilizer treatments (Fig. 5). In any case, the values reflect large amounts of $\mathrm{Fe}$ retained in the root system compared to the shoots. On the other hand, although between 2018 and 2019 there was found an increase in the dry matter yield, the amount of $\mathrm{Fe}$ in the tissues did not increase proportionally, perhaps because it was dependent on the turnover of the root system, since a decrease in root Fe concentrations were observed (Fig. 3). The values of Fe recovery were anyway very high, and comparable to the levels of the $\mathrm{P}$, which is a macronutrient, although $\mathrm{Fe}$ appeared concentrated in the root and $\mathrm{P}$ in greater extent in the aboveground plant parts. The values of Mn recovery in the plant showed some similarities to those of Fe and reflected high experimental variability, since they did not show coherence between the first and second samplings. The Mycorrhiza treatment, for instance, showed a very low result in the first sampling, but its coherence was not maintained in the second sampling one-year latter. The experimental variability mean that other factors have influenced the amount of Mn recovered in the tissues more the than fertilizer treatments. The roots, although they represent less dry matter than stems and leaves, they were the tissues where more Mn was accumulated although in a smaller proportion than observed to Fe.

\subsection{Soil properties}

The fertilizer treatments had a marked effect on soil organic $\mathrm{C}$ (Table 3). The pots receiving the commercial mycorrhizal fungi showed the higher values, whereas the lower levels of soil organic $\mathrm{C}$ were found in the pots receiving a supplemental rate of $\mathrm{N}, \mathrm{P}$ or $\mathrm{K}$. $\mathrm{pH}$ also significantly changed with the fertilizer treatments. The treatment receiving a supplemental rate o $\mathrm{N}(\mathrm{NPK}+\mathrm{N})$ gave the lower values. The application of mycorrhiza seems to have increased the available $\mathrm{P}$ and $\mathrm{K}$ levels in the soil, with values higher $\left(\mathrm{P}_{2} \mathrm{O}_{5}\right)$ or similar $\left(\mathrm{K}_{2} \mathrm{O}\right)$ to the treatments receiving a supplemental rate of the respective nutrient $(\mathrm{NPK}+\mathrm{P}$ and $\mathrm{NPK}+\mathrm{K})$. The control treatment presented the lower values of both nutrients. The NPK + P treatment showed the higher exchangeable $\mathrm{Ca}^{2+}$ values in the soil $\left(24.79 \mathrm{cmol}_{\mathrm{C}} \mathrm{kg}^{-1}\right)$, whereas the lower ones were found in the NPK $+\mathrm{K}$ treatment $\left(21.35 \mathrm{cmol}_{\mathrm{c}} \mathrm{kg}^{-1}\right)$ followed by the NPK $+\mathrm{N}$ treatment $\left(22.01 \mathrm{cmol}_{\mathrm{c}} \mathrm{kg}^{-1}\right)$. Exchangeable $\mathrm{Mg}^{2+}, \mathrm{Na}^{+}$and exchange acidity did not significantly vary with the fertilizer treatments. The higher average values of $\mathrm{K}^{+}$were found in the NPK $+\mathrm{K}$ treatment $(0.31$ $\left.\mathrm{cmol}_{\mathrm{c}} \mathrm{kg}^{-1}\right)$ followed by Mycorrhiza treatment $\left(0.30 \mathrm{cmol}_{\mathrm{c}} \mathrm{kg}^{-1}\right)$, and the lower ones $\left(0.15 \mathrm{cmol}_{\mathrm{c} \mathrm{kg}} \mathrm{kg}^{-1}\right)$ in the Control. The result of cation exchange capacity appeared clearly marked by the result of exchangeable $\mathrm{Ca}^{2+}$, due to the quantitative relevance of this nutrient in the exchangeable complex. Thus, the higher value $\left(32.51 \mathrm{cmol}_{\mathrm{c}} \mathrm{kg}^{-1}\right)$ was found in the NPK $+\mathrm{P}$ treatment and the lower value $\left(28.35 \mathrm{cmol}_{\mathrm{c}} \mathrm{kg}^{-1}\right)$ in the NPK $+\mathrm{N}$ treatment. The levels of the micronutrients $\mathrm{B}, \mathrm{Zn}, \mathrm{Cu}$ and $\mathrm{Mn}$ in the soil did not significantly vary with the fertilizer treatment. The levels of Fe, however, were significantly higher in the pots receiving the commercial product in comparison to the other treatments. 
Table 3

Effect of the fertilizer treatments in selected soil properties. Means followed by the same letter are not significantly different by Tukey HSD test ( $\alpha=0.05$ ).

\begin{tabular}{|c|c|c|c|c|c|c|}
\hline & Control & Mycorrhiza & NPK & $\mathrm{NPK}+\mathrm{N}$ & $\mathrm{NPK}+\mathrm{P}$ & $\mathrm{NPK}+\mathrm{K}$ \\
\hline${ }^{\mathrm{a}}$ Organic C $\left(\mathrm{g} \mathrm{kg}^{-1}\right)$ & $10.8 \mathrm{~b}$ & $11.6 \mathrm{a}$ & $10.1 \mathrm{~d}$ & $10.4 \mathrm{c}$ & $9.4 \mathrm{e}$ & $9.2 \mathrm{f}$ \\
\hline \multicolumn{7}{|l|}{${ }^{\mathrm{b}} \mathrm{pH}$} \\
\hline $\mathrm{H}_{2} \mathrm{O}$ & $6.74 \mathrm{a}$ & $6.62 \mathrm{ab}$ & $6.42 \mathrm{~b}$ & $6.11 \mathrm{c}$ & $6.41 \mathrm{~b}$ & $6.61 \mathrm{ab}$ \\
\hline $\mathrm{KCl}$ & $5.74 \mathrm{bc}$ & $6.06 \mathrm{a}$ & $5.69 \mathrm{c}$ & $5.41 \mathrm{~d}$ & $5.76 \mathrm{bc}$ & $5.95 \mathrm{ab}$ \\
\hline \multicolumn{7}{|l|}{${ }^{\mathrm{c}}$ Extractable $\mathrm{P}$ and $\mathrm{K}$} \\
\hline $\mathrm{P}\left(\mathrm{mg} \mathrm{P} \mathrm{P}_{2} \mathrm{O}_{5} \mathrm{~kg}^{-1}\right)$ & $55.3 \mathrm{e}$ & $314.7 \mathrm{a}$ & $169.3 \mathrm{c}$ & $131.0 \mathrm{~d}$ & $281.7 \mathrm{~b}$ & $158.7 \mathrm{c}$ \\
\hline $\mathrm{K}\left(\mathrm{mg} \mathrm{K}_{2} \mathrm{O} \mathrm{kg}^{-1}\right)$ & $53.3 \mathrm{c}$ & $141.0 \mathrm{a}$ & $107.7 \mathrm{c}$ & $115.3 \mathrm{~b}$ & $112.0 \mathrm{bc}$ & $141.3 \mathrm{a}$ \\
\hline \multicolumn{7}{|l|}{${ }^{\mathrm{d}}$ Exchang. complex } \\
\hline $\mathrm{Ca}^{2+}\left(\mathrm{cmol}_{\mathrm{c}} \mathrm{kg}^{-1}\right)$ & $22.24 \mathrm{ab}$ & $22.92 \mathrm{ab}$ & $23.34 \mathrm{ab}$ & $22.01 \mathrm{~b}$ & $24.79 \mathrm{a}$ & $21.35 \mathrm{~b}$ \\
\hline $\mathrm{Mg}^{2+}\left(\mathrm{cmol}_{\mathrm{c}} \mathrm{kg}^{-1}\right)$ & $5.52 \mathrm{a}$ & $5.63 \mathrm{a}$ & $5.46 \mathrm{a}$ & $5.61 \mathrm{a}$ & $5.76 \mathrm{a}$ & $5.44 \mathrm{a}$ \\
\hline $\mathrm{K}^{+}\left(\mathrm{cmol}_{\mathrm{c}} \mathrm{kg}^{-1}\right)$ & $0.15 \mathrm{e}$ & $0.30 \mathrm{ab}$ & $0.23 \mathrm{~d}$ & $0.27 \mathrm{bc}$ & $0.24 \mathrm{~cd}$ & $0.31 \mathrm{a}$ \\
\hline $\mathrm{Na}^{+}\left(\mathrm{cmol}_{\mathrm{c}} \mathrm{kg}^{-1}\right)$ & $1.57 \mathrm{a}$ & $1.64 \mathrm{a}$ & $1.53 \mathrm{a}$ & $1.63 \mathrm{a}$ & $1.70 \mathrm{a}$ & $1.67 \mathrm{a}$ \\
\hline $\mathrm{EA}\left(\mathrm{cmol}_{\mathrm{c}} \mathrm{kg}^{-1}\right)$ & $0.07 \mathrm{a}$ & $0.01 \mathrm{a}$ & $0.01 \mathrm{a}$ & $0.03 \mathrm{a}$ & $0.02 \mathrm{a}$ & $0.07 \mathrm{a}$ \\
\hline CTCe $\left(\mathrm{cmol}_{\mathrm{c}} \mathrm{kg}^{-1}\right)$ & $29.54 \mathrm{ab}$ & $30.49 \mathrm{ab}$ & $30.56 \mathrm{ab}$ & $29.54 \mathrm{ab}$ & $32.51 \mathrm{a}$ & $28.85 \mathrm{~b}$ \\
\hline \multicolumn{7}{|l|}{ Micronutrients } \\
\hline${ }^{\mathrm{e}} \mathrm{B}\left(\mathrm{mg} \mathrm{kg}{ }^{-1}\right)$ & $0.87 \mathrm{a}$ & $0.98 \mathrm{a}$ & $1.23 \mathrm{a}$ & $1.03 \mathrm{a}$ & $1.12 \mathrm{a}$ & $1.09 \mathrm{a}$ \\
\hline $\mathrm{Fe}\left(\mathrm{mg} \mathrm{kg}^{-1}\right)$ & $133.1 \mathrm{~b}$ & 208.9 a & $146.4 \mathrm{~b}$ & $132.6 \mathrm{~b}$ & $149.9 \mathrm{~b}$ & $146.0 \mathrm{~b}$ \\
\hline${ }^{\mathrm{f}} \mathrm{Zn}\left(\mathrm{mg} \mathrm{kg}^{-1}\right)$ & $3.36 \mathrm{a}$ & $8.21 \mathrm{a}$ & $3.86 \mathrm{a}$ & $5.10 \mathrm{a}$ & $4.19 \mathrm{a}$ & $3.38 \mathrm{a}$ \\
\hline${ }^{\mathrm{f}} \mathrm{Cu}\left(\mathrm{mg} \mathrm{kg}^{-1}\right)$ & $13.28 \mathrm{a}$ & $12.94 \mathrm{a}$ & $13.07 \mathrm{a}$ & $13.73 \mathrm{a}$ & $13.47 \mathrm{a}$ & $9.82 \mathrm{a}$ \\
\hline${ }^{\mathrm{f}} \mathrm{Mn}\left(\mathrm{mg} \mathrm{kg}^{-1}\right)$ & $127.7 \mathrm{a}$ & $164.4 \mathrm{a}$ & $135.6 \mathrm{a}$ & $137.6 \mathrm{a}$ & $116.8 \mathrm{a}$ & $148.6 \mathrm{a}$ \\
\hline \multicolumn{7}{|l|}{ a Walkley-Black. } \\
\hline \multicolumn{7}{|l|}{ b Potentiometry. } \\
\hline \multicolumn{7}{|c|}{ c Ammonium-acetate. } \\
\hline \multicolumn{7}{|c|}{ d Ammonium acetate for bases and potassium chloride for exchangeable acidity (EA), from which effective Cation-Exchange Capacity (CECe) was estimated. } \\
\hline
\end{tabular}

Table 4

Phosphorus labile fraction (Plab) and the sum of Pres (extracted by anionexchange resins) and Pbic (extracted by $\mathrm{NaHCO}_{3} 0.5 \mathrm{M}$ ), and acid phosphatase activity (APA) as a function of the fertilizer treatments. Means followed by the same letter are not significantly different by Tukey HSD test ( $\alpha=0.05)$.

\begin{tabular}{|c|c|c|c|c|c|c|c|c|}
\hline \multirow{2}{*}{$\begin{array}{l}\text { Treatment } \\
\text { Control }\end{array}$} & \multicolumn{2}{|c|}{$\begin{array}{l}\text { Pres (mg } \\
\left.\mathrm{kg}^{-1}\right)\end{array}$} & \multicolumn{2}{|c|}{$\begin{array}{l}\text { Pbic (mg } \\
\left.\mathrm{kg}^{-1}\right)\end{array}$} & \multicolumn{2}{|c|}{$\begin{array}{l}\text { Plab (mg } \\
\left.\mathrm{kg}^{-1}\right)\end{array}$} & \multicolumn{2}{|c|}{$\begin{array}{l}\text { APA }(\mu \mathrm{g} \\
\text { nitrophenol } \mathrm{g}^{-1} \\
\left.\mathrm{~h}^{-1}\right)\end{array}$} \\
\hline & 19.5 & c & 31.1 & c & 50.6 & $\mathrm{c}$ & 302.1 & bc \\
\hline Mycorrhiza & 41.3 & $\mathrm{ab}$ & 116.3 & $\mathrm{a}$ & 157.6 & $\mathrm{a}$ & 377.8 & a \\
\hline NPK & 42.6 & a & 67.1 & b & 109.7 & b & 352.4 & $a b$ \\
\hline $\mathrm{NPK}+\mathrm{N}$ & 23.1 & $\mathrm{bc}$ & 63.0 & $\mathrm{~b}$ & 86.1 & $\mathrm{~b}$ & 221.1 & d \\
\hline $\mathrm{NPK}+\mathrm{P}$ & 53.4 & a & 95.4 & a & 148.8 & $\mathrm{a}$ & 265.2 & $\mathrm{~cd}$ \\
\hline $\mathrm{NPK}+\mathrm{K}$ & 38.8 & $a b c$ & 59.3 & $\mathrm{~b}$ & 98.2 & $\mathrm{~b}$ & 257.3 & $\mathrm{~cd}$ \\
\hline
\end{tabular}

The labile $\mathrm{P}$ fraction in the soil was significantly higher in the Mycorrhiza and NPK + P treatments (Table 4). In the case of the Mycorrhiza treatment, the high Plab value was mainly due to the high level of Pbic, while in the NPK + P treatment it was also due to the Pres fraction. The control treatment showed the lowest values of Pres and Pbic and consequently of Plab. The activity of acid phosphates also varied significantly among treatments, with the Mycorrhiza treatment registering the highest average value.

Easily-extractable glomalin did not significantly varied among the fertilizer treatments (Fig. 6). Total glomalin showed the highest average value in the Mycorrhiza treatment $\left(0.639 \mathrm{mg} \mathrm{g}^{-1} \mathrm{DW}\right)$, which was significantly higher than in the NPK treatment $\left(0.442 \mathrm{mg} \mathrm{g}^{-1} \mathrm{DW}\right)$.

\section{Discussion}

The control treatment registered significantly lower dry matter yield than the fertilized treatments. In pots, it is easier to obtain differences in the performance of plants in non-fertilized control treatments, due to the depletion of essential nutrients in a medium which has limitations for the expansion of the root system (Ferreira et al., 2018a). The olive dry matter yield did not differ between the fertilized treatments. In contrast, a large number of studies on young olive trees have shown beneficial effects from the inoculation with AM fungi compared to non-inoculated plants. Most studies, however, were conducted under conditions limiting plant growth, namely in P-limited soils (Tekaya et al., 2017), plants exposed to drought (Dag et al., 2009; Ouledali et al., 2018), high degrees of salinity (Porras-Soriano et al., 2009) or toxic levels of Mn (Bati et al., 2015). Even so, given the results of this study, this farmer would benefit little from the use of mycorrhiza.

The concentration of $\mathrm{N}$ in all plant tissues showed a marked decrease in the control treatment, seeming to be the main cause of the reduction observed in dry matter yield. In pot experiments, with restrictions on the expansion of the root system, $\mathrm{N}$ can have a strong influence on plant growth and $\mathrm{N}$ nutritional status (Ferreira et al., 2020). In its turn, the treatment receiving a supplementary $\mathrm{N}$ dose $(\mathrm{NPK}+\mathrm{N})$ tended to increase the levels of $\mathrm{N}$ in the plant tissues, but a lower than average dry matter yield, which may indicate an excess of the nutrient available to plants in this treatment. Mycorrhiza treatment did not increase the $\mathrm{N}$ concentration in plant tissues, in comparison to the other treatments which had received an equivalent rate of $\mathrm{N}$. In other studies, however, the use of AM fungi has favoured plant $\mathrm{N}$ uptake (Porras-Soriano et al., 2009; Lanfranco et al., 2016). AM fungi can accelerate decomposition and obtain $\mathrm{N}$ directly from organic material (Hodge et al., 2001). To do this, the most plausible hypothesis is that there is an interaction between AM fungi and protozoa in capturing $\mathrm{N}$ since AM fungi are obligate biotrophs (Koller et al., 2013).

$\mathrm{F}_{\mathrm{V}} / \mathrm{F}_{\mathrm{M}}, \mathrm{F}_{\mathrm{V}} / \mathrm{F}_{0}$, and the OJIP test failed to discriminate between fertilized treatments. Only in one measurement did the control treatment give lower $\mathrm{F}_{\mathrm{V}} / \mathrm{F}_{\mathrm{M}}$ values than the fertilized treatments. Two combined reasons may justify this: the small difference in the nutritional status between the fertilized treatments; and the reduced sensitivity of these measurements to $\mathrm{N}$ nutritional stress (Rodrigues et al., 2017), which was the nutrient registering the greatest difference between the control and the fertilized treatments.

The Mycorrhiza treatment resulted in higher concentrations of $\mathrm{P}$ in plant tissues and P recovery, particularly in the roots. Olive trees tend to accumulate $P$ in the roots when supplied at high rates, which may buffer the concentration of $P$ in the shoots (Ferreira et al., 2018a). The levels of $\mathrm{P}$ in the soil, as extracted with ammonium acetate, were also higher in the Mycorrhiza treatment, even when compared to the treatment that received an additional dose of $\mathrm{P}(\mathrm{NPK}+\mathrm{P})$. The labile $\mathrm{P}$ fraction in the soil was also high in Mycorrhiza and comparable to that which was 


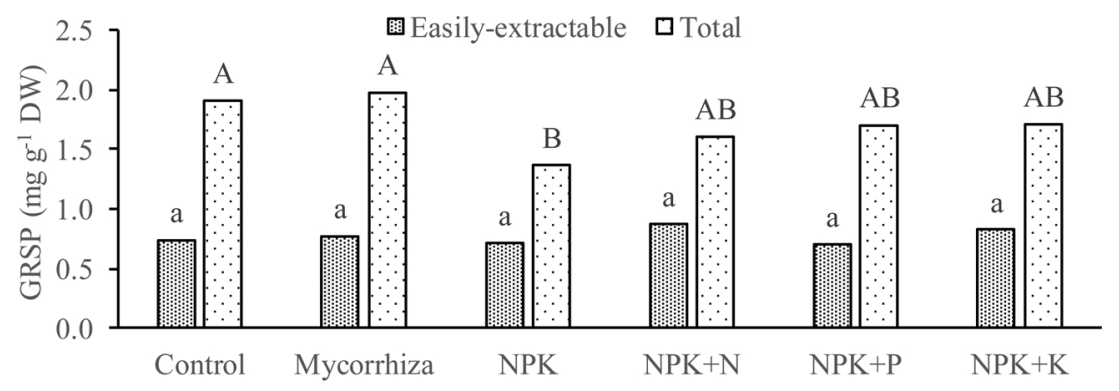

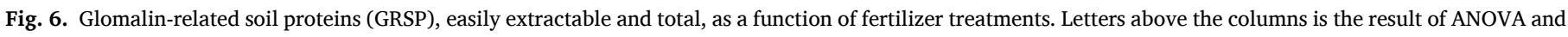
Tukey HSD test ( $\alpha=0.05$ ) separately from Easily-extractable (lowercase) and Total (uppercase) GRSP.

recorded in the NPK + P treatment. The soil samples were sieved in a 2 $\mathrm{mm}$ mesh. The analyzed soil may have contained remains of fine roots, and above all, the network of hyphae or fungal sheaths of the mycorrhizae, and these structures probably contributed to the increase in $\mathrm{P}$ content recorded from the soil analysis. On the other hand, an important role of AM fungi is the provision of soil P to the host plant, since they are more efficient in the uptake of $\mathrm{P}$ which would ordinarily not be available to the majority of plants (Valentine et al., 2013). This is in accordance with the high number of studies involving several crops and growing conditions, in which $\mathrm{P}$ uptake increased in response to the use of AM fungi (Porras-Soriano et al., 2009; Dag et al., 2009; Chatzistathis et al., 2013; Bati et al., 2015; Tekaya et al., 2017). Furthermore, the acid phosphatase activity was also high in the Mycorrhiza treatment. Ectomycorrhizal fungi produce extracellular phosphates and store large amounts of $P$ in the fungal sheaths, releasing it to the plant when its supply is limited (Kieliszewska-Rokicka, 1999; Egerton-Warburton, 2015).

The control treatment resulted in lower K concentrations in the roots than the fertilized treatments. In the olive tree, roots are not a priority sink for $\mathrm{K}$, even though they can store $\mathrm{K}$ as a reserve when the level of the nutrient in the soil is high (Ferreira et al., 2018b). Thus, in the pots of the control treatment, the levels of $\mathrm{K}$ reduced first in the roots. Mycorrhiza and NPK $+\mathrm{K}$ treatments showed higher levels of $\mathrm{K}$ in the soil. As with $\mathrm{P}$, the very thin roots and fungi hyphae may have made a good contribution to this result. Although $\mathrm{K}$ has been a poorly studied element compared to $\mathrm{P}$, there are already studies showing an increased uptake of $\mathrm{K}$ uptake after inoculation with mycorrhizal fungi (Porras-Soriano et al., 2009; Tekaya et al., 2017) and particularly in K-limiting conditions (Garcia and Zimmermann, 2014; Lanfranco et al., 2016).

Fe levels were very high in the plant tissues, in particular the roots. However, the effect of fertilizer treatments, including mycorrhiza, was unclear on the concentration of Fe in plant tissues. In some previous studies, the inoculation of plants with mycorrhiza increased the levels of Fe in plant tissues (Tekaya et al., 2017; Ortas and Bykova, 2018). In this study, a high experimental variability was found, likely due to the wet-drying conditions in the pots. Watering the pots can create zones of decreased redox potential, which usually increases the solubility of $\mathrm{Fe}$ and other nutrients such as Mn (Afonso et al., 2020). However, the most relevant result was the ability of the roots to accumulate $\mathrm{Fe}$ and to prevent its translocation to the shoots. In the roots, the concentration of Fe was about 50 times higher than in the leaves. When in excess in the shoots, ferrous ions can promote the generation of reactive oxygen species and oxidative stress (Dinakar et al., 2010). The main mechanism of resistance by plants to excess Fe is achieved by exclusion: formation of Fe plaque (Fe precipitation on the root surface) and vacuolar storage in roots (Araujo et al., 2020), which was probably what occurred with these plants.

The results of Mn were very similar to those of Fe. However, the concentration of $\mathrm{Mn}$ in the roots, although higher than in the shoots, did not reach the values registered for Fe. Although in several studies the use of AM fungi increased the contents of Mn in plant tissues (Tekaya et al.,
2017; Ortas and Bykova, 2018), the most common result is a restriction in the uptake of Mn and other metals (metals can be retained in AM fungi hyphae) as a way of protecting the plant from excessive uptake and relieving it from the toxic effects of Mn (Nogueira et al., 2007; Bati et al., 2015). Furthermore, ectomycorrhizal fungi can also play an important role in protecting plants against excessive availability of heavy metals, as reported by Luo et al. (2014) and Egerton-Warburton (2015). The role of mycorrhizas was not clear in this study, but olive plants show that they have their own mechanisms to protect the shoots from excess Mn.

From the results of this study, the effect of the treatments on the levels of $\mathrm{Ca}$ and $\mathrm{Mg}$ in plant tissues and soil was found to be small. Although the uptake of $\mathrm{Ca}$ and $\mathrm{Mg}$ may be increased by AM associations, under high concentrations of nutrients in the soil, the symbiotic efficiency tends to decrease (Miransari, 2013; Tekaya et al., 2017). For the micronutrients $\mathrm{B}, \mathrm{Cu}$ and $\mathrm{Zn}$, the effect of treatments was also poor. B appeared regularly distributed through roots, stems and leaves, as observed in other studies (Ferreira et al., 2019). Cu and $\mathrm{Zn}$ appeared more concentrated in the root, although to a lesser extent than Fe. Although studies have shown that in $\mathrm{Zn}$-deficient soils, AM fungi can increase its concentrations in plant tissues (Chatzistathis et al., 2013; Tekaya et al., 2017; Ortas and Bykova, 2018), and even have mechanisms to restrict access of the nutrient to the shoots (Zhan et al., 2018), in this study the immobilization of $\mathrm{Zn}$ and $\mathrm{Cu}$ in the roots seems to have been a mechanism inherent to the plant, as reported for Fe and Mn.

Plants seem not to have benefited from the presence of mycorrhiza in the absorption of most nutrients. Plants pay in photoassimilates for the services provided by the associated fungi. Plants have regulatory mechanisms, known as autoregulation, to control excessive root colonization (García-Garrido et al., 2009; López-Ráez and Pozo, 2013). Furthermore, under high concentrations of nutrients, the symbiotic efficiency of AM usually decreases (Miransari, 2013; Ortas and Bykova, 2018). It has also been postulated that ectomycorrhizal fungi can, depending on the environment, be a benefit or a cost to the host plant (Agren et al., 2019). Thus, an adequate level existing in the soil may explain the reduced effect of the commercial mycorrhizal fungi in the uptake of most of the nutrients analysed.

Soil organic C varied significantly with the fertilizer treatments despite the short duration of the experiment. The Mycorrhiza treatment gave the highest average value and the treatments supplemented with $\mathrm{N}$, $\mathrm{P}$ and $\mathrm{K}(\mathrm{NPK}+\mathrm{N}, \mathrm{NPK}+\mathrm{K}$ and NPK $+\mathrm{P})$ gave the lowest results. The effect of the Mycorrhiza treatment on soil organic $\mathrm{C}$ may have been due, at least in part, to the organic substrate used by the manufacturer as a carrier for propagules. However, positive effects of AM fungi in increasing soil organic matter have also been observed in other studies. Godbold et al. (2006) reported that the external mycelium of mycorrhiza was the dominant pathway (62\%) through which C entered the soil organic matter pool, exceeding the input via leaf litter and fine root turnover. In a well-established association, AM fungi take advantage of C compounds of plant origin, the equivalent of $10-30 \%$ of plant photosynthates (Lanfranco et al., 2016). It has also been suggested that AM fungi reduce decomposition of woody plant litter while increasing soil 
aggregation, which also increases soil C storage (Leifheit et al., 2015). Mineral supplementation reduced the soil organic C, probably due to their effect in reducing the efficiency of micorrhizal colonization, which usually occurs in soils well provided with nutrients (López-Ráez and Pozo, 2013).

Glomalin is a glycosylated soil protein, an important compound in soil organic matter, produced in the hyphal cell walls of AM fungi. GRSP influences aggregation formation, stabilization, and contributes to soil C sequestration. Recent studies have shown a positive relationship between GRSP and soil organic C (Nautiyal et al., 2019; Šarapatka et al., 2019). However, the results from this study were not particularly conclusive about the role of the Mycorriza treatment in GRSP. No significant differences were found in the easily-extractable glomalin between treatments, although the total glomalin leave a tentative clue, in so far as the higher average values were found in Mycorrhiza, the treatment registering the higher organic $\mathrm{C}$ levels.

\section{Conclusions}

The results highlight the relevant role of commercial mycorrhizal fungi in increasing the bioavailability of $\mathrm{P}$, either evaluated by the labile fraction of the soil or through the concentration of the nutrient in the plant tissues. The role of mycorrhiza in increasing soil organic C was also evident, as a probable result of the remobilization of photoassimilates to the fungi and expansion of their hyphae. The role of mycorrhiza on GRSP was modest, even though the highest average value of total glomalin was recorded in the Mycorrhiza treatment. With the exception of a slight increase in the levels of $\mathrm{K}$ in plant tissues, the presence of mycorrhiza does not seem to have benefited the uptake of any other nutrient, possibly because they were not at limiting levels for plant growth. The presence of mycorrhiza also seems not to have played a relevant role in alleviating the excessive levels of metals, in particular Fe, in the shoots, although the plants themselves have shown adequate exclusion mechanisms to restrict its remobilization from roots to shoots. The use of mycorrhizal fungi per se did not improve plant growth compared to other fertilized treatments. The increase in dry matter in the Mycorrhiza treatment, in comparison to the control, was probably due to the enrichment by the biofertilizer with various nutrients such as $\mathrm{N}, \mathrm{P}$ and $\mathrm{K}$.

\section{Funding information}

This research was funded by the Foundation for Science and Technology (FCT, Portugal) and FEDER under Programme PT2020 for financial support to CIMO (UIDB/00,690/2020) and CITAB (UIDB/ $04,033 / 2020$ ). The research was integrated in the activities of the Operational Group "Novas práticas em olivais de sequeiro: estratégias de mitigação e adaptação às alterações climáticas”, funded by PT2020 and EAFRD (European Agricultural Fund for Rural Development).

\section{Author contributions}

M Ângelo Rodrigues conceptualized the project and established the basis for the experimental design, with the collaboration of Carlos Correia, Lucas Domingues and Luís Cassol. He was also responsible for the first draft of the manuscript, which was reviewed by Carlos Correia, Lucas Domingues and Luís Cassol. Margarida Arrobas is the head of the Lab of Soil Testing and Plant Analysis where all the soil and plant analysis were processed. She supervised all analytical determination. Valkiria Piroli and Douglas Forcelini carried out the pot experiments, having received help from Soraia Raimundo in the laboratory.

\section{Declaration of Competing Interest}

The authors report no declarations of interest.

\section{References}

Aeron, A., Kharel, E., Jha, C.K., Meena, V.S., Aziz, S.M.A., Islam, M.T., Kim, K., Meena, S. K., Pattanayak, A., Rajashekara, H., Dubey, R.C., Maurya, B.R., Maheshwari, D.K., Saraf, M., Choudhary, M., Vermal, R., Meena, H.N., Subbanna, A.R.N.S., Parihar, M., Shukla, S., Mutthusamy, G., Bana, R.S., Bajpai, V.K., Han, Y.-K., Rahman, M., Kumar, D., Singh, N.P., Meena, R.K., 2020. Revisiting the plant growth-promoting rhizobacteria: lessons from the past and objectives for the future. Arch. Microbiol. 202, 665-676. https://doi.org/10.1007/s00203-019-01779-w.

Afonso, S., Arrobas, M., Rodrigues, M.A., 2020. Soil and plant analyses to diagnose hop fields irregular growth. J. Soil Sci. Plant Nutr. https://doi.org/10.1007/s42729-02000270-6.

Ågren, G.I.A., Hyvönen, R., Baskaran, P., 2019. Ectomycorrhiza, friend or foe? Ecosystems 22, 1561-1572. https://doi.org/10.1007/s10021-019-00356-y.

Alef, K., Nannipieri, P., Trazar-Cepeda, C., 1995. Phosphatase activity. In: Alef, K. Nannipieri, P. (Eds.), Methods in Applied Soil Microbiology and Biochemistry. Academic Press, San Diego, pp. 214-215.

Andrade-Linares, D.R., Franken, P., 2013. Fungal endophytes in plant roots: taxonomy, colonization patterns, and functions. In: Aroca, R. (Ed.), Symbiotic Endophytes. Springer-Verlag, Berlin, Heidelberg, pp. 311-333.

Araujo, T.O., Isaure, M.-P., Alchoubassi, G., Bierla, K., Szpunar, J., Trcera, N., Chav, S., Alcon, C., Silca, L.C., Curie, C., Mari, S., 2020. Paspalum urvillei and Setaria parviflora, two grasses naturally adapted to extreme iron-rich environments. Plant Physiol. Biochem. 151, 144-156.

Balbino, L.R., 1968. La méthode Egner-Riehm et la détermination du phosfore et du potassium «assimilável» des sols du Portugal. II Col. Medit Cont. Fert. Plantas Cultivadas, pp. 55-65.

Bati, C.B., Santilli, E., Lombardo, L., 2015. Effect of arbuscular mycorrhizal fungi on growth and on micronutrient and macronutrient uptake and allocation in olive plantlets growing under high total Mn levels. Mycorrhiza 25 (2), 97-108.

Bunzel, K., Kattwinkel, M., Schauf, M., Thrän, D., 2014. Energy crops and pesticide contamination: lessons learnt from the development of energy crop cultivation in Germany. Biomass Bioenerg. 70, 416-428.

Calvo-Polanco, M., Sánchez-Romera, B., Aroca, R., 2013. Arbuscular mycorrhizal fungi and the tolerance of plants to drought and salinity. In: Aroca, R. (Ed.), Symbiotic Endophytes. Springer-Verlag, Berlin, Heidelberg, pp. 271-288.

Chatzistathis, T., Orfanoudakis, M., Alifragis, D., Therios, I., 2013. Colonization of Greek olive cultivars' root system by arbuscular mycorrhiza fungus: root morphology, growth, and mineral nutrition of olive plants. Sci. Agric. 70 (3), 185-194.

Dag, A., Yermiyahu, U., Ben-Gal, A., Zipori, I., Kapulnik, Y., 2009. Nursery and posttransplant field response of olive trees to arbuscular mycorrhizal fungi in an arid region. Crop Pasture Sci. 60 (5), 427-433. https://doi.org/10.1071/CP08143.

Dinakar, C., Abhaypratap, V., Yearla, S.R., Raghavendra, A.S., Padmasree, K., 2010. Importance of ROS and antioxidant system during the beneficial interactions of mitochondrial metabolism with photosynthetic carbon assimilation. Planta 231, $461-474$.

Egerton-Warburton, L., 2015. Aluminum-tolerant Pisolithus ectomycorrhizas confer increased growth, mineral nutrition, and metal tolerance to Eucalyptus in acidic mine soil. Appl. Environ. Soil Sci. 9. https://doi.org/10.1155/2015/803821. Article ID 803821 .

Ferrando, L., Fernández-Scavino, A., 2013. Functional diversity of endophytic bacteria. In: Aroca, R. (Ed.), Symbiotic Endophytes. Springer-Verlag, Berlin, Heidelberg, pp. 195-211.

Ferreira, I.Q., Rodrigues, M.A., Moutinho-Pereira, J.M., Correia, C., Arrobas, M., 2018a. Olive tree response to applied phosphorus in field and pot experiments. Sci Hort 234, 236-244. https://doi.org/10.1016/j.scienta.2018.02.050.

Ferreira, I.Q., Arrobas, M., Moutinho-Pereira, J.M., Correia, C., Rodrigues, M.A., 2018b. Olive response to potassium applications under different water regimes and cultivars. Nutr. Cycl. Agroecosys 112, 387-401. https://doi.org/10.1007/s10705018-9954-2.

Ferreira, I.Q., Rodrigues, M.A., Arrobas, M., 2019. Soil and foliar applied boron in olive: tree crop growth and yield, and boron remobilization within plant tissue. Span. J. Agric. Res. 17 (1), e0901 https://doi.org/10.5424/sjar/2019171-13796.

Ferreira, I.Q., Arrobas, M., Moutinho-Pereira, J.M., Correia, C.M., Rodrigues, M.A., 2020. The effect of nitrogen applications on the growth of young olive trees and nitrogen use efficiency. Turk. J. Agric. For. 44, 278-289. https://doi.org/10.3906/tar-190526.

Fischer, S., Príncipe, A., Alvarez, F., Cordero, P., Castro, M., Godino, A., Jofré, E., Mori, G., 2013. Fighting plant diseases through the application of Bacillus and Pseudomonas strains. In: Aroca, R. (Ed.), Symbiotic Endophytes. Springer-Verlag, Berlin, Heidelberg, pp. 165-193.

Garcia, K., Zimmermann, S.D., 2014. The role of mycorrhizal associations in plant potassium nutrition. Front. Plant Sci. 17. https://doi.org/10.3389/fpls.2014.00337.

García-Garrido, J.M., Lendzemo, V., Castellanos-Morales, V., Steinkellner, S. Vierheilig, H., 2009. Strigolactones, signals for parasitic plants and arbuscular mycorrhizal fungi. Mycorrhiza 19, 449-459.

Godbold, D.L., Hoosbeek, M.R., Lukac, M., Cotrufo, M.F., Janssens, I.A., Ceulemans, R., Polle, A., Velthorst, E.J., Scarascia-Mugnozza, G., Angelis, P., Miglietta, F., Peressoti, A., 2006. Mycorrhizal hyphal turnover as a dominant process for carbon input into soil organic matter. Plant Soil 281 (1-2), 15-24.

Hodge, A., Campbell, C.D., Fitter, A.H., 2001. An arbuscular mycorrhizal fungus accelerates decomposition and acquires nitrogen directly from organic material. Nature 413 (6853), 297-299.

Jones Jr., J.B., 2001. Laboratory Guide for Conducting Soil Tests and Plant Analysis. CRC Press, Boca Raton, USA. 
Kieliszewska-Rokicka, B., 1999. Phosphate status and acid phosphatase activity in soil and ectomycorrhizas in two mature stands of scots pine (Pinus sylvestris L.) exposed to different levels of anthropogenic pollution. Acta Soc. Bot. Pol. 68 (4), 311-317.

Koller, R., Rodriguez, A., Robin, C., Scheu, S., Bonkowski, M., 2013. Protozoa enhance foraging efficiency of arbuscular mycorrhizal fungi for mineral nitrogen from organic matter in soil to the benefit of host plants. New Phytol. 199 (1), 203-211. https://doi.org/10.1111/nph.12249.

Lanfranco, L., Bonfante, P., Genre, A., 2016. The mutualistic interaction between plants and arbuscular mycorrhizal fungi. Microbiol. Spectr. 4 (6), 1-20. https://doi.org/ 10.1128/microbiolspec.FUNK-0012-2016.

Leifheit, E.F., Verbruggen, E., Rillig, M.C., 2015. Arbuscular mycorrhizal fungi reduce decomposition of woody plant litter while increasing soil aggregation. Soil Biol. Biochem. 81, 323-328. https://doi.org/10.1016/j.soilbio.2014.12.003.

López-Ráez, J.A., Pozo, M.J., 2013. Chemical signalling in the arbuscular mycorrhizal symbiosis: biotechnological applications. In: Aroca, R. (Ed.), Symbiotic Endophytes. Springer-Verlag, Berlin, Heidelberg, pp. 215-232.

Luo, B., Wu, C., Zhang, C., Li, H., Lipka, U., Polle, A., 2014. The role of ectomycorrhizas in heavy metal stress tolerance of host plants. Environ. Exp. Bot. 108, 47-62. https:// doi.org/10.1016/j.envexpbot.2013.10.018.

Mendivil-Garcia, K., Amabilis-Sosa, L.E., Rodríguez-Mata, A.E., Rangel-Peraza, J.G., Gonzalez-Huitron, V., Cedillo-Herrera, C.I.G., 2020. Assessment of intensive agriculture on water quality in the Culiacan River basin, Sinaloa, Mexico. Environ. Sci. Pollut. Res. https://doi.org/10.1007/s11356-020-08653-z.

Miransari, M., 2013. Arbuscular mycorrhizal fungi and uptake of nutrients. In: Aroca, R. (Ed.), Symbiotic Endophytes. Springer-Verlag, Berlin, Heidelberg, pp. 253-270.

Nautiyal, P., Rajput, R., Pandey, D., Arunachalam, K., Arunachalam, A., 2019. Role of glomalin in soil carbon storage and its variation across land uses in temperate Himalayan regime. Biocatal. Agric. Biotechnol. 21, 01-11. https://doi.org/10.1016/ j.bcab.2019.101311.

Nogueira, M.A., Nehls, U., Hampp, R., Poralla, K., Cardoso, E.J.B.N., 2007. Mycorrhiza and soil bacteria influence extractable iron and manganese in soil and uptake by soybean. Plant Soil 298, 273-284. https://doi.org/10.1007/s11104-007-9379-1.

Ortas, I., Bykova, A., 2018. The effect of mycorrhiza inoculation and phosphorus application on phosphorus efficiency of wheat plants. Commun. Soil Sci. Plant Anal. 49, 1199-1207. https://doi.org/10.1080/00103624.2018.1455849.

Ouledali, S., Ennajeh, M., Zrig, A., Gianinazzi, S., Khemira, H., 2018. Estimating the contribution of arbuscular mycorrhizal fungi to drought tolerance of potted olive trees (Olea europaea). Acta Physiol. Plant. 40 (5), 80-93. https://doi.org/10.1007/ s11738-018-2656-1.

Porras-Soriano, A., Soriano-Martín, M.L., Porras-Piedra, A., Azcón, R., 2009. Arbuscular mycorrhizal fungi increased growth, nutrient uptake and tolerance to salinity in olive trees under nursery conditions. J. Plant Physiol. 166 (13), 1350-1359. https:// doi.org/10.1016/j.jplph.2009.02.010.

Remy, W., Taylor, T.N., Hass, H., Kerp, H., 1994. Four hundred-million-year-old vesicular arbuscular mycorrhizae. Proc. Nat. Acad. Sci. U.S.A. 91, 11841-9111843. https://doi.org/10.1073/pnas.91.25.11841.

Rodrigues, M.A., Afonso, S., Ferreira, I.Q., Arrobas, M., 2017. Response of stevia to nitrogen fertilization and harvesting regime in Northeastern Portugal. Arch. Agron. Soil Sci. 63 (5), 626-637. https://doi.org/10.1080/03650340.2016.1230272.

Rodrigues, M.A., Ladeira, L.C., Arrobas, M., 2018. Azotobacter-enriched organic manures to increase nitrogen fixation and crop productivity. Eur. J. Agron. 93, 88-94. https://doi.org/10.1016/j.eja.2018.01.002.

Šarapatka, B., Alvarado-Solano, D.P., Čižmár, D., 2019. Can glomalin content be used as an indicator for erosion damage to soil and related changes in organic matter characteristics and nutrients? Catena 181, 104078. https://doi.org/10.1016/j. catena.2019.104078.

Tekaya, M., Mechri, B., Mbarki, N., Cheheb, H., Hammami, M., Attia, F., 2017. Arbuscular mycorrhizal fungus Rhizophagus irregularis influences key physiological parameters of olive trees (Olea europaea L.) and mineral nutrient profile. Photosynthetica 55, 308-316. https://doi.org/10.1007/s11099-016-0243-5.

Temminghoff, E.E.J.M., Houba, V.G., 2004. Plant Analysis Orocedures, 2nd ed. Klwuwer Academic Publishers, AA Dordrecht, The Netherlands.

Valentine, A.J., Mortimer, P.E., Kleinert, A., Kang, Y., Benedito, V.A., 2013. Carbon metabolism and costs of arbuscular mycorrhizal associations to host roots. In: Aroca, R. (Ed.), Symbiotic Endophytes. Springer-Verlag, Berlin, Heidelberg, pp. 233-252.

Van Reeuwijk, L.P., 2002. Procedures for soil analysis. Technical Paper 9, $6^{\text {th }}$ ed. ISRIC, FAO.

Vessey, J.K., 2003. Plant growth promoting rhizobacteria as biofertilizers. Plant Soil 255, 571-586. https://doi.org/10.1023/A:1026037216893.

Wright, S.F., Upadhyaya, A., 1998. A survey of soils for aggregate stability and glomalin, a glycoprotein produced by hyphae of arbuscular mycorrhizal fungi. Plant Soil 198, 97-107. https://doi.org/10.1023/A:1004347701584.

Wu, Q.S., Zou, Y.N., 2010. Beneficial roles of arbuscular mycorrhizas in citrus seedlings at temperature stress. Sci. Hort. 125, 289-293. https://doi.org/10.1016/j. scienta.2010.04.001.

Zhan, F., Li, B., Jiang, M., Yue, X., He, Y., Xia, Y., Wang, Y., 2018. Arbuscular mycorrhizal fungi enhance antioxidant defence in the leaves and the retention of heavy metals in the roots of maize. Environ. Sci. Pollut. Res. 25, 24338-24347. https://doi.org/10.1007/s11356-018-2487-z. 